\title{
PET Containers in Brazil: A Logistics Model for Post-Consumer Waste Recycling
}

\author{
Tatiene Martins Coelho, Rosani de Castro and José Alcides Gobbo Junior \\ Faculdade de Engenharia de Bauru, Universidade Estadual Paulista (UNESP), \\ Brazil
}

\section{Introduction}

Over recent decades, demographic growth, unprecedented industrialization and competitiveness for new markets have made companies face the issue of the environmental impact caused by their production processes and by the generation of post-consumption residue from their products.

In view of this, companies now have an emergent concern regarding this generation of residue, the return of which must be considered, thus providing a business opportunity through reverse logistics.

Environmental consideration is no longer regarded as a trend but a way of life for industry. For many companies over the past few decades, there has been a shift in addressing environmental issues. Actions that were taken at the operational level due to regulative demands are now being discussed at the strategic level (Nilsson, 2001). The idea of sustainability must consider the interplay of social, economic and environmental aspects with integrated and long-term perspectives.

Since the early 90s in Europe, there have been effective actions taken in order to reduce the amount of packaging, as well as its final disposal. One of the goals of the European Union was to reduce the amount of packaging waste by $70 \%$ by the year 2006 . In order to achieve this goal, it is important to consider the recycling of this product since its inception (Onusseit, 2005).

Brazil is one of the fastest growing consumer markets for PET bottles, however, the country lacks an organized recycling system. This study will analyze, in an integrated manner, the best alternative to improve the recycling system by examining the PET bottle life-cycle in Brazil. Initially, Brazil's recycling of PET containers will be described. It should be noted that there are no specific laws or regulations determining responsibility for manufacturing, collection, recycling and final disposal of materials. Subsequently, an alternative system for recycling will be proposed considering social, economic, and environmental aspects with an integrated, long-term perspective.

The objective of this chapter is to outline the panorama of the post-consumption PET return system and propose a fitting application aimed at reducing the volume of residue. 


\section{The solid waste problematic}

Countries that direct their model of development exclusively towards the economic, seek unbridled growth and an intensification of their economic activities. As a consequence, they assist in the accelerated urbanization process and the continuous transformations of nature. They also cause great disequilibrium because, if on one side they produce technological advances, on the other, they contribute towards growth in misery, environmental degradation and pollution (Cavalcanti, 1995).

According to (Tenório \& Espinosa, 2004), the human being is the only one able to conduct the large scale transformation of raw materials into finished products, spewing unknown substances into the environment, which cannot be absorbed even over the long term, thus generating residue that, if not well administered, could result in pollution. From an environmental perspective, this pollution could be divided into three different classes: air pollution, water contamination and solid waste.

The Brazilian Association of Waste Treatment, Recovery and Disposal Companies reports that every year Brazil generates nearly 2,9 million tons of solid waste, 600 thousand tons, or $22 \%$, of which receive proper treatment. Of the treated industrial rejects, $16 \%$ goes to landfills, $1 \%$ is incinerated and the remaining $5 \%$ is co-processed, that is, transformed through burning into raw materials sued for manufacturing cement (Abetre, 2008).

In face of the waste treatment, recovery and disposal context, the National Waste Policy (PNRS, 2002) has been in proceedings at the federal level since 1991. In article 12, it attributes solid waste management generated in the Federal District and cities to those respective territories.

According to (NBR 10004, 2004), solid waste may be present in solid and semi-solid states, which result in activities of industrial, household, hospital, commercial, agricultural, service and sweeping origin. This definition includes sludge from water treatment systems; sludge generated in pollution control equipment and installations, as well as certain liquids whose particularities make it unfeasible for release into the public sewage network or water bodies, or requires technical and economically unfeasible solutions for such in face of the best technology available.

In an international context, according to (Mahmood \& Victor, 2001), there are many variables involved in managing solid wastes, which hamper decision making for implementing policies directed towards solid wastes.

For (Calderoni, 2003) says the definition and conceptualization of the terms "garbage", "waste" and "recycling" differ according to the situation in which they are applied. Their use in current language indeed stands out from other meanings adopted consonant to the institutional perspective or in accordance with their economic meaning; in current language, the term waste is practically a synonym of garbage. Garbage is all useless material. It designates all discarded material, put in some public location. It is the object or substance considered useless or whose existence in a given environment is considered harmful. Waste is a word often adopted to mean left over from the production, generally industrial, process.

One of the evident problems in Brazil concerns management of urban solid waste, especially when dealing with environmental impacts and the preservation of natural resources. The 
environmental impact caused by the unbridled production of solid waste has led the government and society to promote studies for alternatives that aim at minimizing the degradation of nature and increasing society's well-being as a whole.

According to (Scholz, 1993), final disposal and treatment of waste can be done using the following methods: landfills (disposal of household waste in the soil); energetic recycling (incineration or burning of hazardous waste, reusing and transforming the energy generated); organic recycling (composting of organic matter); industrial recycling (reuse and transformation of recyclable materials) and steam sterilization and microwave disinfection (treatment of pathogenic, septic and hospital waste).

Solid waste management activities, according to (Cunha \& Caixeta Filho, 2002), can be grouped into six functional elements: generation, packaging, collection, transfer/transshipment stations and/or processing and/or final disposal.

According to (Machado et al., 2006), to achieve sustainable development, it is necessary to join efforts by all of society, without exclusion of any segments, characterizing the importance of the implementation study and the development of recyclable material collection cooperatives in cities as a whole, specifically at industries.

Even with the creation of measures and procedures that aim at reducing the indiscriminate use of products and actions that harm the environment, the difficulty in disposing of urban garbage is still one of the most serious environmental problems.

\section{PET bottle: Recycling and reverse logistics}

Recycling involves reintroducing into the system, part of the material and energy that would otherwise be waste. It is an alternative for reducing waste; however, some aspects regarding the benefits and the reuse of recyclable material have to be clarified (Grimberg \& Blauth, 1998).

According to (Manzini \& Vezzoli, 2005), extending the lifespan of materials means making them last longer than the products they are part of, i.e. materials can be re-processed into secondary raw materials. This is called recycling and can take place through two distinct processes:

a. Closed loop recycling: a production system in which the waste or byproduct of one process or product is used in making another product or derived component. In theory, this process can be used for a certain period of time without introduction of virgin materials;

b. Open loop recycling: A recycling system in which a product made from one type of material is recycled into a different type of product. This occurs normally in postconsumer materials. In this process, different products and manufacturers may be involved.

Recycling involves reintroducing into the system, part of the material and energy that would otherwise be waste. It is an alternative for reducing waste; however, some aspects regarding the benefits and the reuse of recyclable material have to be clarified (Grimberg \& Blauth, 1998). 
The main difficulty in maximizing recycling is related to the costs involved in the process, one should take into account the costs from collection, transportation and warehousing to material commercial value.

(Clinton et al., 2010) suggest that the closed-loop recycling is the best environmental option and must also take into account other factors that influence the cost of material collection and treatment. According to (Awaja \& Pavel, 2005), in addition to the environmental incentive, recycling of PET as an industry is getting its driving force from the increasing value and applications of virgin and modified PET.

Various technologies have been developed for PET bottles and plastic waste. These methods include (Kawamoto, 2008):

a. material recycling in which the plastic waste is reprocessed into molded products;

b. "bottle-to-bottle" process, in which PET bottle waste is reused as raw material for new PET bottles;

c. a method in which plastic waste is used as a reducing agent in the blast furnace; and

d. a method in which plastic waste is thermally decomposed in the coke oven, producing oil and coke oven gas to be used as industrial raw materials.

Determining an overall recycling rate that takes into account social, economic and environmental aspects is a very interesting strategy for industrial organizations (McBean et al., 2005; Singh et al., 2009; Barboza et al., 2009).

Reverse logistics includes: development of products, inventories, restocking, market withdrawals and excess inventory. It also includes programs for recycling hazardous materials, and disposal of obsolete equipment and resource recovery. It can be said that recycling is the reverse channel of reverse logistics or post-consumer logistics, once it adds value after use and avoids the product life cycle to terminate at the point of the final consumer.

The main perspectives that need to be considered in relation to reverse logistics include not only networking and inventory, but also the collection of post-consumer products, its price, its use, resale and re-manufacturing through an established system. The literature on reverse logistics is, according to (Pokharel \& Mutha, 2009) based on three major groups, defined by inputs, structure and processes and outputs.

Reverse logistics is the process of moving post-consumer (end-of-life industrial waste) as well as post-market (returnable due to a manufacturer defect or warranty issues) materials, from its disposal to its reinstatement in the business cycle, without causing major environmental impacts.

The reverse logistics flow must be sustainable, because this process deals with much broader issues than simple returns. The materials involved in this process can be returned to the supplier, resold, refurbished, recycled or simply discarded and replaced.

\subsection{Post-consumer PET bottles in Brazil}

The PET bottle is a post-consumer waste and its disposal is not regulated by any legislation in Brazil. The reintegration of these products into a new production cycle relies on the 
initiative of recyclable material collectors who deliver these materials to scrap dealers, who in turn refer to recycling companies.

Market trends and technological advances have spurred new applications for recycled PET. Recycling is used to produce polyester fiber for the textile industry, the manufacture of ropes and bristles of brooms and brushes, shower stalls, thermoforming and vacuum forming machinery, traffic and general signs, which adds value to business. Currently, the largest market for post-consumer PET in Brazil is the production of polyester fiber for the textile industry (Cempre, 2009).

PET is currently present in the most diverse products. Brazil has the following history of consumption/recycling over the past 10 years, as per Table 1:

\begin{tabular}{c|c}
\hline Years & Recycling (Post Consumer/Índex) \\
\hline 1999 & 50,0 Ktonnes $=20,4 \%$ \\
2000 & 67,0 Ktonnes $=26,3 \%$ \\
2001 & 89,0 Ktonnes $=32,9 \%$ \\
2002 & 105,0 Ktonnes $=35,0 \%$ \\
2003 & 141,5 Ktonnes $=43,0 \%$ \\
2004 & 167,0 Ktonnes $=47,0 \%$ \\
2006 & 174,0 Ktonnes $=47,0 \%$ \\
2007 & 194,0 Ktonnes $=51,3 \%$ \\
2008 & 231,0 Ktonnes $=53,5 \%$ \\
2009 & 253,0 Ktonnes $=54,8 \%$ \\
\hline
\end{tabular}

Table 1. Recycling of post-consumer PET in Brazil from 1999 to 2009, Source: ABIPET (2011)

In 2009, 521,800 tons of PET resins were consumed in Brazil for the manufacture of packaging. From this, $55.6 \%$ of post-consumer packaging was effectively recycled. In order to minimize the issue of inappropriate waste disposal in the environment, recycling is encouraged through enterprise associations or individual companies who believe this to be an alternative to preserve natural resources, reduce the cost of processing raw materials and promote social inclusion (Abipet, 2011). Many Brazilian municipalities do not perform any type of collection and few have a selective waste collection system. The bottles are recovered primarily through scavengers, in addition to factories and the selective collection carried out by municipalities.

In 2006, 51.3\% of PET consumed in Brazil was reintegrated into the market through recycling, and in 2009 , the recycling rate was $55.6 \%$. It is estimated that the recycling rate will continue to grow, and eventually reach that of aluminum cans recycling which is above $98 \%$ post-consumer recycling.

According to (Abipet, 2011), PET bottles in Brazil are mostly widely used as packaging material for food, which accounts for approximately $90 \%$ of the packaging industry. Most of the recycled PET in Brazil is intended for the textile industry.

It is also observed in Brazil the growth of the applications of PET in apparel, accounting for $44 \%$ of recycled PET (Abipet, 2011). The wide use of post-consumer recycled PET in tissue 
fibers may generate a potential environmental problem, because the material has a short life cycle and could be inappropriately disposed. The most environmentally friendly process to reintegrate this material to its production cycle is the manufacture of new bottles, even for non-food products. The intention in the use of recycled PET is presented by ABIPET (2011) who describes the intention of users to increase or maintain the consumption of resin.

Although Brazil has felt the reflexes of a global economic crisis that began in 2008, no reduction in consumption or recycling pace was observed. However, the PET recycling industry in Brazil has an idleness rate of about $30 \%$, which makes the sector capable of quickly absorbing any volume, without any investment (Abipet, 2011).

Post-consumption recycling of PET guaranteed Brazil second place in the world for recycling the product, as in Table 2.

\begin{tabular}{cc}
\hline Countries & Post-consumer PET recycling rate (\%) \\
\hline Japan (2008) & 77,9 \\
Brazil (2009) & 55,6 \\
Europe (2009) & 48,4 \\
Australia (2007) & 42,3 \\
Argentina (2008) & 34,0 \\
United States (2009) & 28,0 \\
Mexico (2009) & 18,1 \\
\hline
\end{tabular}

Table 2. Post-consumer PET recycling rate around the world, Source: ABIPET - PET Recycling Census in Brazil 2009-2010, (2011)

In face of the need to reduce residue at a global level, the use of recycled PET is an alternative to increase the useful life of landfills since it is material that takes a long time to degrade in the environment (Coelho et al., 2008).

According to data from (Abipet, 2011), the destination for most recycled PET is the textile industry, as seen in Table 3.

\begin{tabular}{l|r|r|r}
\hline Transformation PET & $\mathbf{2 0 0 7}$ & $\mathbf{2 0 0 8}$ & $\mathbf{2 0 0 9}$ \\
\hline Textiles & $50,5 \%$ & $38 \%$ & $39 \%$ \\
Sheet and Laminates & $13,1 \%$ & $15 \%$ & $15 \%$ \\
Thermoformers & $12,0 \%$ & - & - \\
Chemical Resins & $6,1 \%$ & $18 \%$ & $19 \%$ \\
Exportation & $5,8 \%$ & - & - \\
Injection and Blow & $4,1 \%$ & - & - \\
Tapes & $3,6 \%$ & $7 \%$ & $6 \%$ \\
Engineering Plastics & $3,2 \%$ & - & - \\
Packaging & $1,7 \%$ & $1 \%$ & $2 \%$ \\
Others & - & $21 \%$ & $19 \%$ \\
\hline
\end{tabular}

Source: ABIPET - PET Recycling Census in Brazil 2007-2010, (2011).

Table 3. Destination of PET in Brazil from 2007 to 2009 
The PET bottles in Brazil are mostly widely used as packaging material for food, which accounts for approximately $90 \%$ of the packaging industry; however, the destination for the largest volume of recycled PET in Brazil is in the textile industry (Abipet, 2011).

It is believed that the market is adapting and evolving with respect to the use of plastic waste, particularly PET.

The wide use of post-consumer recycled PET in tissue fibers may generate a potential environmental problem, because the material has a short life cycle and could be inappropriately disposed. The most environmentally friendly process to reintegrate this material to its production cycle is the manufacture of new bottles, even for non-food products. The intention in the use of recycled PET is presented by (Abipet, 2011) who describes the intention of users to increase or maintain the consumption of resin.

\section{Considerations of the Brazilian PET post-consumer}

It appears that effective actions are needed in Brazil to increase PET recycling; however, it is important to emphasize that collection and transportation are important steps when dealing with a process that involves costs. In the case of PET bottles, these moments are critical, since Brazil does not have a legislation requiring the manufacturer or the consumer to appropriately dispose of the post-consumer material. The key players in the process, and specifically the consumer, must be made aware of their duties and responsibilities.

The logistics flow of bottles begins in PET resin production and continues with the manufacture of pre-forms in specific companies or in beverage manufacturing companies. After filling, the product is sent to the retailer where it will be purchased by consumers who will eventually dispose of the bottle. The Brazilian reality of post-consumer PET bottles can be summarized by the individual collection performed by scavengers who survive from the economic activity provided by the trash.

In Brazil, the activity of scavengers is a reality based on the great social inequality. Struggling to survive, the scavenger becomes an important environmental agent, preserving the environment either by cleaning public places and lengthening the useful life of landfills, or by increasing the life cycle of materials (Mota, 2005).

According to data from (Cempre, 2009), in Brazil, approximately 200,000 street scavengers are responsible for collecting various materials. However, few of them live off garbage by choice, or simply to supplement the family income. Many of those living in slums and suburbs work for more than 10 hours and cover more than $12 \mathrm{~km} /$ day. Some work with their children and infants, tossing bags of garbage and not having regular meals (Machado, 2006). After collection, the material is sent to intermediaries, which reduces the profit of the scavengers, since it must be resold to its final destination for recycling. As a result of recycling, new products are manufactured as shown in Figure 1.

Analysis of the Brazilian system of post-consumer PET shows the need for changes in the PET bottles reintegration system. It is necessary to take into account the importance of economic, social and environmental impacts of the new proposals for post-consumer logistics in order to organize the reverse channel and increase the amount of material sent 
for recycling as well as reduce the rate of inappropriate disposal at landfills, dumping areas, rivers, oceans and public roads.

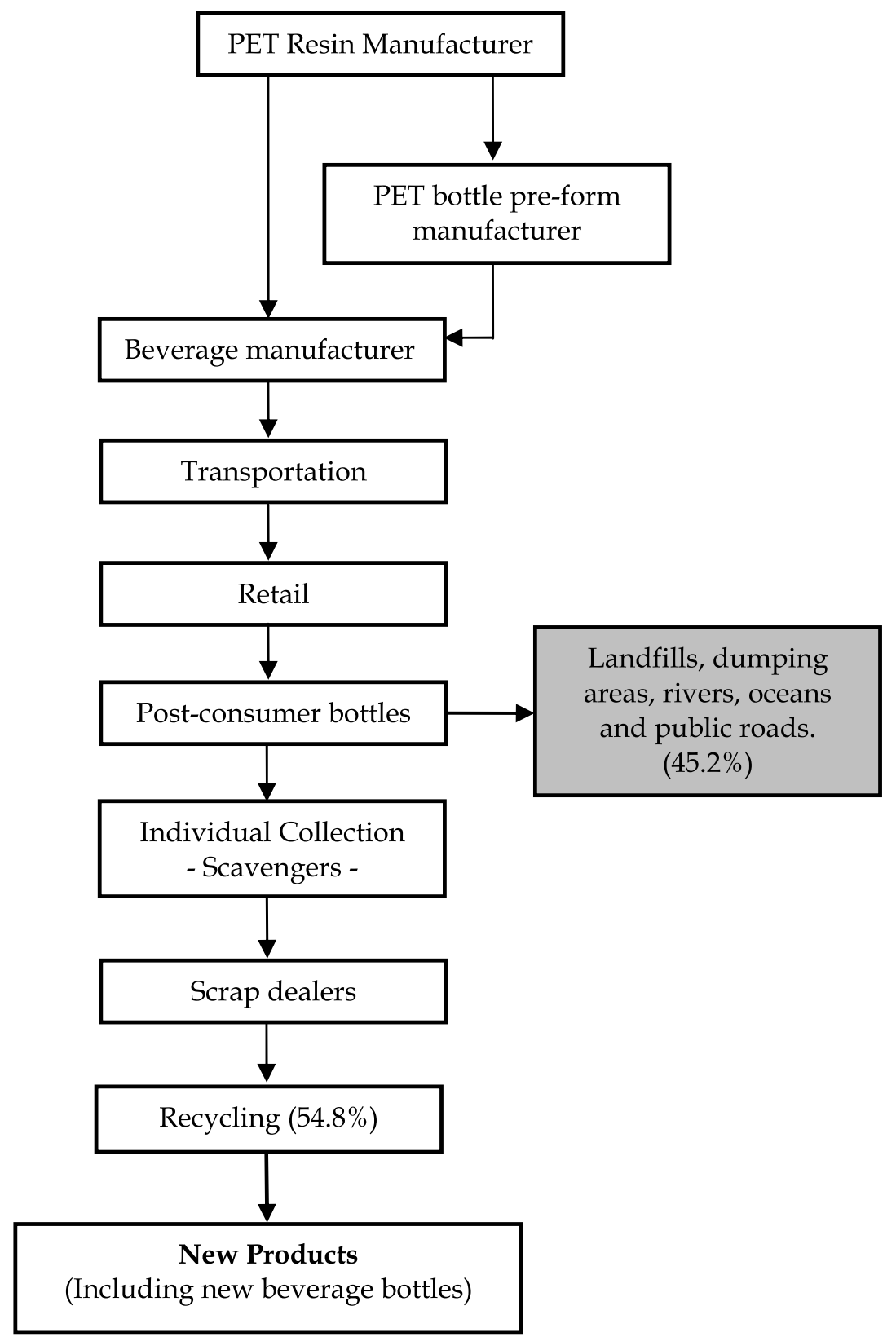

Fig. 1. Post-consumer PET Reintegration System in Brazil 
Recycling is considered one of the most important tools to aid waste treatment and disposal, as well as a way of generating employment and income for a growing number of people.

\subsection{Environmental aspects}

According to (Boustead \& Lidgren, 1984), the environmental effect of the PET bottle recycling system could be analyzed from a solid waste, energy use, pollution emissions, water pollution, hygiene, public health impacts and urban traffic congestion perspective.

The most environmentally effective strategy is one using less materials and processes with the least energy (Saphire, 1994).

According to (Boustead \& Lidgren, 1984), the environmental effect of the PET bottle recycling system could be analyzed from a solid waste, energy use, pollution emissions, water pollution, hygiene, public health impacts and urban traffic congestion perspective.

The most environmentally effective strategy is one using less materials and processes with the least energy (Saphire, 1994).

In Brazil, the PET bottle is a post-consumer waste which its disposal is not regulated by any laws. The reintegration of the product to a new production cycle relies on the initiative of scavengers or recycling cooperatives who receive recyclable material through selective waste collection.

The boom of PET bottle recycling and the advances in technology, boosts new applications for recycled PET and facilitate the plastic waste removal from the landfill, reducing its impact on the environment. Only 55.6\% of post-consumer PET containers were recycled effectively, a rate that can be improved if actions are effectively implemented by the government. Nowadays, recycling is accomplished through different business actions or individual companies. Recycling, on the environmental aspect, contributes to reducing soil, water and air pollution, extends landfill life, improves public sanitation, etc.

A solution to the PET waste is to maximize the reduction of the amount of such waste at the source. In Brazil, there are isolated initiatives by some manufacturing companies, but there isn't a policy established by the government to standardize environmentally friendly procedures for these companies.

\subsection{Economics aspects}

It is impossible to establish a sustainable product system without dealing with, not only environmental aspects, but also economic impact appropriately.

Recapturing value in recycling is the step of performing the decontamination and appropriateness of the collected material so that it can be used as raw material in manufacturing. The manufacturing industry uses the material and transforms it into another marketable product, the recycled product. The correct equation of the reverse logistics of post-consumer packaging is to make possible the recycling of PET.

The reverse logistics is the process by which recyclable material is collected, sorted and delivered to the industry. This creates an impasse, because who pays for the reverse logistics 
industry is neither the packaging goods companies nor the packaged goods industry, but society as a whole.

Today, society pays more for not having proper reverse logistics, different from what occurs with other countries - USA, Australia, Japan and all Europe.

PET recycling brings many economic benefits such as: reduction of the volume of garbage collected, which is transported to landfills; electrical power and oil savings, because most plastics are derived from oil; employment generation (scavengers, scrap dealers, workers, etc.); lower prices to the consumer of recycled plastic products; mechanical recycling of PET bottles requires less energy needed to produce the raw material, approximately $30 \%$ cheaper than those products manufactured with virgin raw materials; mechanical recycling of plastic beverage packaging (PET) which requires, on average, only $30 \%$ of the energy needed for raw material production.

Decreasing the amount PET waste that is sent to landfils reduces the municipality's cost of waste management. In addition, increasing its sorted collection enhances the transport from the retailer to the recycling plant. On the other hand, increasing PET waste transportation promotes increasing costs to the industry since beverage companies are responsibe for transportation of PET waste (Amano, 2004).

\subsection{Social aspects}

According to (Abipet, 2011), although the recycled PET packaging originates in alternative collection systems done by scavengers and their cooperatives, or by companies dedicated to this task, a large portion of the packaging ends up being sent to dumping areas. This is a common system in Brazil for the disposal of municipal solid waste. The two main reasons for this are a lack of garbage collection, mainly in poorer communities, and a habit of Brazilians for discarding trash into the rivers and streets.

According to (Abipet, 2011), although actually recycled PET packages originate in alternative collection systems, such as garbage pickers and their cooperatives or companies dedicated to that task, an important portion of the packages end up sent to garbage dumps, the most common system in Brazil for disposing of urban solid waste.

This occurs for two main reasons: first due to the lack of garbage collection, because not every Brazilian city has garbage collection for $100 \%$ of all domiciles, especially in the poorest districts and shantytowns; second, due to the Brazilian population's habit of getting rid of the package by throwing it in common garbage or, when it is not collected, in the rivers and streets.

The collection in dumping areas results in serious problems. On the one hand, it is possible to observe Brazilian adults and children in unhealthy and sub-human conditions scavenging for food, subjecting themselves to different forms of contagion and infection in an effort to find products to sell. Moreover, the product collected in landfills is heavily contaminated with grease, paints, heavy metals and dirt in general. The contaminated package requires a more expensive cleaning process, which devalues the package.

Another relevant point is that the collector receives a reduced value for the material, either because the product is contaminated, or by action of an intermediary who resells the product to the recycling industry. 
In Brazil, alternative collection systems for PET packaging carried out by scavengers and cooperatives, contribute to recruiting unskilled people. By discarding the waste properly, society contributes to preserving the environment and to achieving continuous improvement in quality of life. This enables the development of standards and working conditions as well as the development of social responsibility in products and services.

System limitations focus on the consumer, who is still not fully informed about the possibility of recycling and, consequently, the economic value of the post-consumption PET bottle; with that, packaging ends up getting disposed of in common garbage. Furthermore, the lack of efficient selective collection systems impedes bottle recovery, which end up lost in landfills and garbage dumps.

\section{Proposal for a Brazilian system for post-consumer PET}

It appears that effective actions are needed in Brazil to increase PET recycling; however, it is important to emphasize that collection and transportation are important steps when dealing with a process that involves costs. In the case of PET bottles, these moments are critical, since Brazil does not have a legislation requiring the manufacturer or the consumer to appropriately dispose of the post-consumer material. The key players in the process, and specifically the consumer, must be made aware of their duties and responsibilities.

The logistics flow of bottles begins in PET resin production and continues with the manufacture of pre-forms in specific companies or in beverage manufacturing companies. After filling, the product is sent to the retailer where it will be purchased by consumers who will eventually dispose of the bottle. The Brazilian reality of post-consumer PET bottles can be summarized by the individual collection performed by scavengers who survive from the economic activity provided by the trash.

In Brazil, the activity of scavengers is a reality based on the great social inequality. Struggling to survive, the scavenger becomes an important environmental agent, preserving the environment either by cleaning public places and lengthening the useful life of landfills, or by increasing the life cycle of materials (Mota, 2005).

According to data from (Cempre, 2009), in Brazil, approximately 200,000 street scavengers are responsible for collecting various materials. However, few of them live off garbage by choice, or simply to supplement the family income. Many of those living in slums and suburbs work for more than 10 hours and cover more than $12 \mathrm{~km} /$ day. Some work with their children and infants, tossing bags of garbage and not having regular meals (Machado, 2006). After collection, the material is sent to intermediaries, which reduces the profit of the scavengers, since it must be resold to its final destination for recycling.

Analysis of the Brazilian system of post-consumer PET shows the need for changes in the PET bottles reintegration system. It is necessary to take into account the importance of economic, social and environmental impacts of the new proposals for post-consumer logistics in order to organize the reverse channel and increase the amount of material sent for recycling as well as reduce the rate of inappropriate disposal at landfills, dumping areas, rivers, oceans and public roads. 
Recycling is considered one of the most important tools to aid waste treatment and disposal, as well as a way of generating employment and income for a growing number of people.

The discussion on the current reintegration system for post-consumer PET in Brazil indicates the need for a new post-consumer logistics proposal, aiming at economic, social and environmental opportunities that will provide a sustainable reverse system. Figure 2 proposes three distinct paths for post consumer PET bottles in the new reverse system.

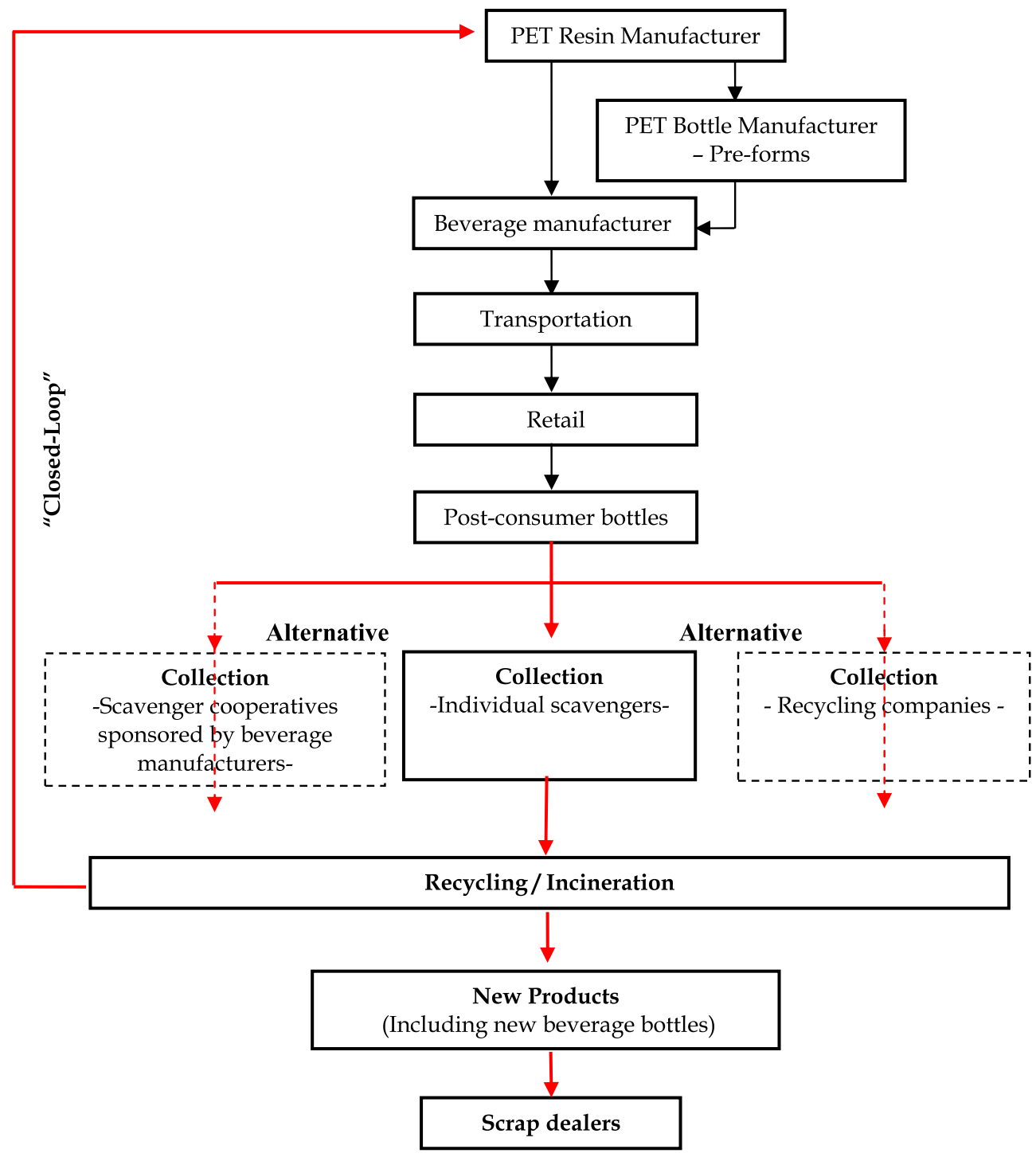

Fig. 2. Proposal for a reintegration system for post-consumer PET bottles in Brazil 
The challenges of this new logistics flow for post-consumer PET bottles are concentrated in the pursuit of the following:

a. public policies concerning the responsibility for waste generated in the production process;

b. the development of strategies for the appropriate destination of PET bottles (transport mechanisms, collection, recycling and recovery of material) for the introduction of cooperatives;

c. social mainstreaming tools; and

d. the assignment of the responsibility in each cycle (production, purchase, consumption and disposal) in order to reduce the use of raw materials, waste and disposal.

All of these collection mechanisms are aimed to remove the post-consumer PET waste and send them for recycling. According to (Chilton et al., 2010), the recycling of PET results in a net reduction in the emissions of $\mathrm{CO}_{2}$, carbon monoxide, acid gases, particulate matter, heavy metals and dioxins. This is due to the reduction in the emissions associated with manufacturing an equivalent mass of PET from virgin materials.

In the proposed logistics flow, the post-consumer bottles are obtained through: selective collection performed by scavenger cooperatives subsidized by the municipality or by the beverages manufacturers; spontaneous participation or imposed by environmental legislation; door-to-door collection (residences and points of consumption) performed by individual scavengers; and retail collection by recyclers. Collection characterization:

a. By individual scavengers: it is expected that $30 \%$ of the post-consumer PET bottles sent for recycling will return through these door-to-door scavengers, since they need this activity as a means of income. A successful collection relies on consumer awareness and the ability to sort out these materials.

b. By scavenger cooperatives subsidized by the municipality or by the beverages manufacturers: assuming that the company is responsible for the waste generated through the production process, it is possible to consider the establishment of scavenger cooperatives as a way to organize the activity and incurring gains for their own production without being exploited. This enables the development of social and health projects by achieving a better quality of life. Besides the economic and social issues related to cooperatives, the environmental aspect is also very important, because the cooperatives contribute to reducing the environmental impact of consumption. It is important that the government encourages the establishment of scavenger cooperatives, formalizing a longstanding marginalized activity, assisting with the allocation of infrastructure investments for the recovery of citizenship in the segment. In the proposed reverse system, the cooperatives are subsidized by the public and private sectors (beverage manufacturers). Investment from private companies that use PET for packaging their drinks are claimed by public policies. In this case, it is expected that $50 \%$ of the post-consumer PET bottles sent for recycling will return through these cooperatives.

c. By recyclers: these are companies that will benefit directly from the recycling of PET bottles. The collection points at retail would be an opportunity to expand the number of post-consumer PET bottles collected. In this case, it is expected that $20 \%$ of the post- 
consumer PET bottles sent for recycling will remain the responsibility of these players. The success of the activity also relies on the consumer to play its part.

All of these collection mechanisms are aimed to remove the post-consumer PET waste and send them for recycling. According to (Chilton et al., 2010), the recycling of PET results in a net reduction in the emissions of $\mathrm{CO}_{2}$, carbon monoxide, acid gases, particulate matter, heavy metals and dioxins. This is due to the reduction in the emissions associated with manufacturing an equivalent mass of PET from virgin materials.

Another option for the final destination of post-consumer PET bottles is incineration, because this material is capable of generating energy. According to (Chilton et al., 2010), waste PET can be recovered by collecting it with the non-recyclable household waste followed by burning it in an energy-from-waste incineration plant.

Once the PET waste is capable of generating power, the possibility exists that the collected material will be sold directly to factories to be used as a power generation source. This destination somehow does not interfere with the collection system. In addition to recylcling, it is just one more option of an appropriate destination for the material.

Jointly held shares enable the socialization of costs and contributes directly to the environment by generating other products. There is also the opportunity to transform recycled materials into new food packaging that is regulated by ANVISA.

In the proposed post-consumer logistics system, it is essential that the duties and responsibilities are divided among the various key players involved in the recycling chain. System maintenance is done through private sector investments and government intervention at the municipal, state and federal levels through public policies.

\section{Conclusion}

The data presented enabled the identification of the need for effective actions, aimed at increasing the amount of recycled PET. In Brazil, it is necessary to focus on post-consumer PET bottles, because the ones that are not recycled are inappropriately disposed in the environment. The need for structuring the distribution reverse channels becomes relevant, since there are limiting factors in relation to increasing the levels of PET bottle recycling.

According to (Manzini \& Vezzoli, 2005), the collection and transportation stages should not be underestimated, either in terms of planning reverse logistics or in relation to environmental impact. Often, this stage affects the economy and the environmental benefits of recycling. In the case of PET bottles, the stage of recycling is fundamental, since there isn't a legislation requiring the manufacturer or the consumer to appropriately dispose of postconsumer material. The key players in the process, and specifically the consumer, must be made aware of their duties and responsibilities

The analysis of the Brazilian system of post-consumer PET bottles under environmental, economic and social aspects favored the proposal for a reintegration system for postconsumer PET with opportunities for the development of a sustainable reverse system. It also presents several challenges such as: the need for a national policy on solid waste and municipal and state actions to make the reverse logistics viable and strengthen the Brazilian 
recycling industry; the need to increase awareness of the key players involved in the postconsumer PET reverse chain structure; the need for consumption reduction in order to reduce the waste generated; and the need to engage industrial sectors and the government, through public policies, to support cleaner technologies along the PET bottle production chain.

Some of the difficulties related to the inclusion of the reintegration system for post consumer PET are: the costs related to the total life cycle, as the company becomes liable for its product up to the end of its lifespan; a greater integration of the production chain, assigning responsibilities and the degree of cooperation in the chain; development of larger reverse logistics management controls and information systems to facilitate the integration of reverse logistics to the normal flow of distribution.

By implementing this system, the company will be able to account for the environmental costs of their products in order to comply with environmental laws and minimize the environmental impact generated by their products. It will also allow value to be recaptured and be strategically used as a competitive edge, demonstrating the company's commitment to a sustainable development.

\section{References}

. NBR 10004. Resíduos sólidos - classificação. Rio de Janeiro, 2004.

Abipet Associação Brasileira dos Fabricantes de Embalagens PET. Reciclagem de Embalagens PET. Disponível em: http:/ / www.abipet.com.br. Acesso: 15 ago. 2011.

Associação Brasileira de Empresas de Tratamento, Recuperação e Disposição de Resíduos Especiais - ABETRE. Disponível em:

<http://www.ambientebrasil.com.br/composer.php3?base=./residuos/index.php $3 \&$ conteudo=./residuos/lixo.html>. Acesso em 18 fev. 2008.

Associação Brasileira de Embalagem - ABRE. Disponível em <http:/ / www.abre.org.br/meio_reci_brasil.php>. Acesso em 08 fev. 2010.

Amano, M. PET Bottle System in Sweden and Japan: an Integrated Analysis from a LifeCycle Perspective. Lund, Sweden; 2004.

Awaja F., PAVEL, D.. Review Recycling of PET. European Polymer Journal 2005 41: 1453-1477

Barboza ES, Lopez DR, Amicoa SC, Ferreira CA . Determination of a recyclability index for the PET glycolysis. Resources, Conservation and Recycling, 2009 53: 122-128

Boustead, I; Lidgren, K. Problems in Packaging - the Environmental Issue. Wiley \& Sons, Incorporated, John, 1984..

Brasil. Política Nacional de Resíduos Sólidos. Ministério do Meio Ambiente: Brasília, versão II, 2002. Disponível em: <www.mma.gov.br>. Acesso em: 10 jun. 2010.

Calderoni, S. Os bilhões perdidos no lixo. São Paulo: Humanitas, 2003.

Cavalcanti, C. Desenvolvimento e natureza: estudos para uma sociedade sustentável. São Paulo: Cortez, 1995.

Cempre - Compromisso Empresarial para a Reciclagem. Disponível em: <http:/ / www.cempre.org.br>. Acesso em: 29 nov. 2009.

Chilton T, Burnley S, Suresh N. A life cycle assessment of the closed-loop recycling and thermal recovery of post-consumer PET. Journal Resources, Conservation and Recycling, 2010. 
Coelho, T.M; Castro, R; Batistelle, R.A.G. Analysis of the post-consumption reverse channel of the pet bottle in brazil. POMS 20th Annual Conference. In: Anais..., Orlando, Florida U.S.A., 2009

Cunha, V., Caixeta Filho, J. V. Gerenciamento da coleta de resíduos sólidos urbanos: estruturação e aplicação de modelo não-linear de programação por metas. Gestão \& Produção. São Carlos, v. 9, n. 2, ago. 2002.

Grimberg E, Blauth P. Coleta Seletiva reciclando materiais, reciclando valores. São Paulo: Polis, 1998.

Kawamoto K. Waste Recycling Technologies Required by a Sound Material-Cycle Society. Quaterly Review 2008; 27.

Machado, BA, et al. A importância social e econômica da implementação de cooperativas de materiais recicláveis. Associação Brasileira de Engenharia de Produção. XXVI ENEGEP Fortaleza, 2006. Disponível em: <http://www.abepro.org.br/biblioteca/ENEGEP2006_TR560372_8549.pdf>. Acesso em 25 maio. 2010.

Mahmood, N. Z.; Victor, D. Policy approach in life cycle of solid waste management in Malaysia. Life Cycle Management. In: 1st International Conference on Lyfe Cycle Management. Conpenhagen, Denmark, p .301-4, aug. 2001.

Mcbean EA, Del Rosso E, Rovers FA. Improvements in financing for sustainability in solid waste management. Journal Resources, Conservation and Recycling 2005 43:391401.

Mota, AV.; Do Lixo à Cidadania. Artigo. Democracia Viva, n. 27. Instituto Brasileiro de Análises Sociais e Econômicas. Rio de Janeiro. 2005. Disponível em:

< http://www.ibase.br/pubibase/media/dv27_artigo1_ibasenet.pdf>. Acesso em 25 mai. 2010.

Nilsson I. Integrating environmental management to improve strategic decision-making', Chalmers University of Technology Report, XX Environmental System Analysis 2001.

Onusseit, H. The influence of adhesives on recycling: A review. Journal Resources, Conservation and Recycling 2005 (46), 168-181.

Saphire, D. Case Reopened - Reassessing Refillable Bottles. Inform Strategies for a better environment: New York, 1994.

Singh RK, Murty HR, Gupta SK, Dikshit AK. An overviewof sustainability assessment methodologies. Ecol Indicators 2009;9:189-212.

Scholz, L.C. Coleta, tratamento e disposição final: problemas e perspectivas. In: São Paulo. Secretaria do Meio Ambiente. Coordenadoria de Educação Ambiental. Resíduos Sólidos e Meio Ambiente. São Paulo: Pini, 1993.

Tenório, J.A.S; Espinosa, D.C.R. Curso de gestão ambiental. Barueri, SP: Manole, 2004. 


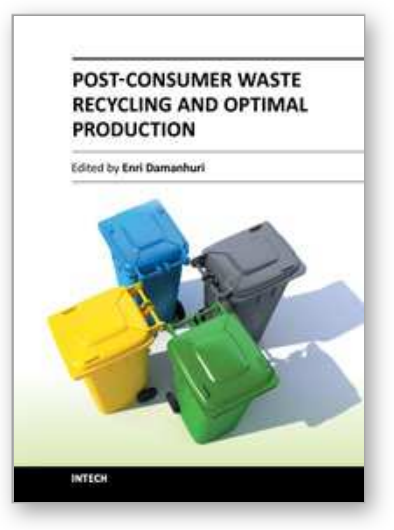

\author{
Post-Consumer Waste Recycling and Optimal Production \\ Edited by Prof. Enri Damanhuri
}

ISBN 978-953-51-0632-6

Hard cover, 294 pages

Publisher InTech

Published online 23, May, 2012

Published in print edition May, 2012

This book deals with several aspects of waste material recycling. It is divided into three sections. The first section explains the roles of stakeholders, both informal and formal sectors, in post-consumer waste activities. It also discusses waste collection programs for recycling. The second section discusses the analysis tools for recycling system. The third section focuses on the recycling process and optimal production. I hope that this book will convey both the need and means for recycling and resource conservation activities to a wide readership, at both academician and professional level, and contribute to the creation of a sound materialcycle society.

\title{
How to reference
}

In order to correctly reference this scholarly work, feel free to copy and paste the following:

Tatiene Martins Coelho, Rosani de Castro and José Alcides Gobbo Junior (2012). PET Containers in Brazil: A Logistics Model for Post-Consumer Waste Recycling, Post-Consumer Waste Recycling and Optimal Production, Prof. Enri Damanhuri (Ed.), ISBN: 978-953-51-0632-6, InTech, Available from: http://www.intechopen.com/books/post-consumer-waste-recycling-and-optimal-production/pet-containers-inbrazil-a-reverse-logistics-model-post-consumer

\section{INTECH}

open science | open minds

\section{InTech Europe}

University Campus STeP Ri

Slavka Krautzeka 83/A

51000 Rijeka, Croatia

Phone: +385 (51) 770447

Fax: +385 (51) 686166

www.intechopen.com

\section{InTech China}

Unit 405, Office Block, Hotel Equatorial Shanghai

No.65, Yan An Road (West), Shanghai, 200040, China 中国上海市延安西路65号上海国际贵都大饭店办公楼405单元

Phone: +86-21-62489820

Fax: +86-21-62489821 
(C) 2012 The Author(s). Licensee IntechOpen. This is an open access article distributed under the terms of the Creative Commons Attribution 3.0 License, which permits unrestricted use, distribution, and reproduction in any medium, provided the original work is properly cited. 